\title{
ORIGINAL ARTICLE \\ First molecular evidence of an invasive agricultural pest, Drosophila suzukii, in the diet of a common bat, Pipistrellus pipistrellus, in Belgian orchards
}

\author{
Daan Dekeukeleire ${ }^{1,}{ }^{*}$, René Janssen $^{2}$, Robert Delbroek ${ }^{2}$, Stijn Raymaekers ${ }^{3}$, Femke Batsleer ${ }^{1}$, \\ Tim Belien ${ }^{3}$, Eero J. Vesterinen ${ }^{4,5}$
}

\author{
${ }^{1}$ Department of Biology, Terrestrial \\ Ecology Unit, Ghent University, Ghent, \\ Belgium. \\ ${ }^{2}$ Valderstraat 39, $6171 \mathrm{EL}$, Bionet \\ Natuuronderzoek, Stein, The \\ Netherlands. \\ ${ }^{3}$ Zoology Department, Pcfruit vzw, Sint- \\ Truiden, Belgium. \\ ${ }^{4}$ Department of Agricultural Sciences, \\ University of Helsinki, Helsinki, Finland. \\ ${ }^{3}$ Department of Biology, University of \\ Turku, Turku, Finland. \\ *Corresponding author: \\ daan.dekeukeleire@gmail.com
}

\begin{abstract}
Bats are major consumers of arthropods, including many agricultural pest species, and can thus reduce and prevent crop damage. However, few, if any, data is available on the potential role of bats in pest control in central Europe. Evidence that bats prey upon locally important pest species would be an important first step to demonstrate their value to local farmers and facilitate conservation measures. In this pilot study, we used a DNA metabarcoding approach to investigate the diet composition of common pipistrelles and brown long-eared bats captured in orchards in Belgium. We show that the spotted wing drosophila (Drosophila suzukii), one of the most harmful pest species in this region, was part of the diet of common pipistrelles. This pest species was recorded in one of the five samples from common pipistrelles. Our results indicate that bats can be valuable assets for biological pest suppression in West-European orchards, thus setting a path for future studies.
\end{abstract}

DOI: https://doi.org/10.14709/BarbJ.13.1.2020.18

Keywords: ecosystem services, eDNA, faecal DNA, invasive alien species, orchards, pest control, Spotted Wing Drosophila.

\section{INTRODUCTION}

Farmers are increasingly confronted with the need to consider all available pest control techniques and select appropriate measures, while minimizing risks to human health and the environment. Such integrated pest management (FAO 2020) encourages natural pest control. Many bat species, with diverse foraging strategies, forage intensively in agricultural systems and can thus deliver such an ecosystem service (Boyles et al. 2011, Russo et al. 2018). Recent studies using molecular methods to investigate diet composition have shown that bat species prey upon pest species. For instance, a study at several sites across southern Europe shows that the diet of Miniopterus schreibersii includes more than 40 agricultural pest species affecting diverse crop types, ranging from rice paddies to corn fields, to olive groves (Aizpurua et al. 2018). Moreover, large-scale field experiments in both tropical and temperate zone agricultural systems show that predation by bats can control herbivorous insect populations, and cascading effects can lead to increased crop yields (Maas et al. 2013, Maine \& Boyles 2015). Yet, scarce data is available from central and northern Europe (Russo et al. 2018). Evidence that bats prey upon locally important pest species is the first step to demonstrate their value to local farmers and to stimulate further studies.
One such agricultural pest species is Drosophila suzukii, an invasive species of Asian origin that affects a wide range of soft-skinned fruits such as blueberries, blackberries, plums and cherries. Since its introduction in the late 2000's this species spread rapidly across North America and Europe (Asplen et al. 2015). Contrary to many other Drosophila species, females of $D$. suzukii deposit their eggs in intact ripening fruits, after which their larvae rapidly destroy the fruits (Rota-Stabelli et al. 2013). For farmers, the use of insecticides is often not effective because the larvae develop deep enough inside the fruit to avoid contact. There are currently no effective and environmentally sustainable pest control methods for this species, resulting in extensive damage to fruit crops in Europe and North America (Schetelig et al. 2018). For instance, in Belgium, since its first record in 2011 (Mortelmans et al. 2012), D. suzukii has become the most important pest species in orchards, leading to yearly economic losses of ca. 20 million euro (Belien et al. 2014, Nijland 2015).

Many species of bats forage intensively in European orchards (Stahlschmidt et al. 2017). A recent study recorded $D$. suzukii in the diet of Rhinolophus hipposideros, Pipistrellus pipistrellus and P. kuhlii (Galan et al. 2018) in Western France. By DNA metabarcoding faeces from captured bats, we set out to investigate if bats foraging in Belgian orchards prey upon $D$. suzukii. 


\section{MATERIAL AND METHODS}

\section{Field sampling}

In May and August 2016, bats were captured with mist nets (Ecotone, Poland) whilst they were foraging in orchards in the Limburg region in Belgium (Table 1). In this region, high activity of Pipistrelle bats has been observed during acoustic surveys in orchards. Captured bats were kept individually in clean cotton bags for up to $30 \mathrm{~min}$, and droppings were collected from the bag and stored in pure ethanol. At three sites, samples from different captured individuals were pooled (see Table 1). Additionally, two maternity roosts situated in the middle of orchards were visited, and fresh droppings were collected (Table 1). Droppings were stored at room temperature until extraction. Apart from $P$. pipistrellus and Plecotus auritus, we also captured Myotis bechsteinii, but could not collect faeces of this species within the $30 \mathrm{~min}$ time span. Bat captures and handling was carried out under license and guidelines from the Belgian authorities (permit ANB/BL-FF/V15-00095). All bats were released unharmed at the capture site.

\section{DNA extraction}

DNA was extracted from the 8 faecal samples (one to three pooled droppings; see Table 1) using ZR-96 Fecal DNA Kit (cat. nr D6011; Zymo Research Corp., Irvine, USA). We used whole droppings as starting material (samples dried briefly on clean paper). DNA was eluted into $100 \mu \mathrm{L}$ of BE buffer and stored at $-20^{\circ} \mathrm{C}$ until analysis.

\section{PCR and library construction}

We used a single primer pair to amplify the mitochondrial cytochrome c oxidase subunit I gene (COI) of potential prey (ZBJ-ArtF1C and ZBJ-ArtR2c; Zeale et al. 2011). Despite the potential bias in these primers toward some Orders (Diptera and Lepidoptera; Clarke et al. 2014), we chose COI region because of the well-developed reference library and these specific primers to allow comparison of our results with earlier studies (eg. Krüger et al. 2014, Rydell et al. 2016, Vesterinen et al. 2016, 2018, Aizpurua et al. 2018). The PCR and library construction closely followed Kaunisto et al. (2017). The first-step PCR reactions-prepared in two replicates-included locus-specific primers targeting prey COI gene, and the second PCR followed directly after this including Illumina-specific adapters with a unique dual-index combination for each single reaction. Cycling conditions for COI were $3 \mathrm{~min}$ in $95^{\circ} \mathrm{C}$, then 16 cycles of $30 \mathrm{~s}$ in $95^{\circ} \mathrm{C}, 30 \mathrm{~s}$ in $61^{\circ} \mathrm{C}$ (with the annealing temperature decreased by $0.5^{\circ} \mathrm{C}$ for each cycle) and $30 \mathrm{~s}$ in $72^{\circ} \mathrm{C}$, then additional 24 cycles of $30 \mathrm{~s}$ in $95^{\circ} \mathrm{C}, 30 \mathrm{~s}$ in $53^{\circ} \mathrm{C}$ and $30 \mathrm{~s}$ in $72^{\circ} \mathrm{C}$ ending with $3 \mathrm{~min}$ in $72^{\circ} \mathrm{C}$. The samples were pooled by equal volume ( $2 \mu$ l each library) and purified using dual-SPRI (Solid Phase Reversible Immobilisation) beads following the protocol in Vesterinen et al. (2016). Sequencing was performed on an Illumina MiSeq platform at the Functional Genomics Unit (FuGU) of the University of Helsinki, Finland using v2 (300 cycles) $2 \times 150$ bp paired-end sequencing Bioinformatics and prey list construction.
The Illumina sequencing as a whole yielded 10,161,700 paired-end reads identified to samples with unique dualindex combinations. Trimming and quality control of the sequences were conducted according to Vesterinen et al. (2018). Consequently, paired-end reads were merged and trimmed for quality using program USEARCH (Edgar 2010). Primers were removed using the program cutadapt (Martin 2011). The reads were then collapsed into unique sequences (singletons removed), after which the sequences were clustered into zero-radius operational taxonomical units (ZOTU; Edgar 2016) and mapped back to the original trimmed reads to establish the total number of reads in each sample using USEARCH 'unoise3' algorithm. In short, the UNOISE algorithm allows detection and removal of chimeras (PCR artefacts where two fragments of different origin bind together) and point errors (substitutions and gaps resulting from incorrect or omitted base calls), and results in zero-radius OTUs (ZOTUs). After processing, our dataset consisted of 141,369 prey reads. The data was filtered so that each ZOTU was discarded from samples where only one replicate produced reads (reducing the stochasticity of the PCR) for that specific sample. Furthermore, ZOTU was discarded from the sample if fewer reads were found from that sample compared to any negative control (reducing the effect of so-called tag jumping or sample cross-talk). Finally, we compared our ZOTU sequences to the BOLD reference database, which is by far the most comprehensive curated COI database (Ratnasingham \& Hebert 2007). We used the following criteria for including prey species in the final data: (1) sequence similarity with the reference sequence of minimum $96 \%$ for the ZOTU to be given any - even higher order taxa - assignation, (2) minimum ten reads of the assigned prey species and (3) assigned prey species recorded in Belgium (https://observations.be). After the above trimming, we identified and retained $77.34 \%$ of the prey reads.

To visualize the prey use for both bat species, we analyzed the data using package 'bipartite' (Dormann et al. 2009) in $R \vee 3.4 .3$ (R core team 2017) to construct quantitative and semi-quantitative bipartite graphs based on relative read abundance (RRA; number of OTU reads/sum of all OTU reads) and percentage of occurrences (POO; Deagle et al. 2019 ) in the samples. The most common prey items (relative read abundance of at least $15 \%$ for RRA data; percentage of occurrences of at least $5 \%$ for POO data) were highlighted in the bipartite graphs.

\section{RESULTS}

In this study, we analysed five samples of Pipistrellus pipistrellus and three of Plecotus auritus. We recovered 37 taxa of 22 arthropod families (Table 2; Fig. 1). D. suzukii was found in one of the five samples from $P$. pipistrellus (sample ID 4 in Table 1). In this sample of a single individual, D. suzukii was the most abundantly recovered taxon, accounting for $29.87 \%$ of the reads. Across the sequenced region, these reads were between 97.4 and $100 \%$ identical only to sequences of $D$. suzukii in BOLD.

Apart from D. suzukii, we recorded several other species that can cause agricultural damage in the investigated samples, namely Tipula oleracea, Delia platura and Autographa 
A.
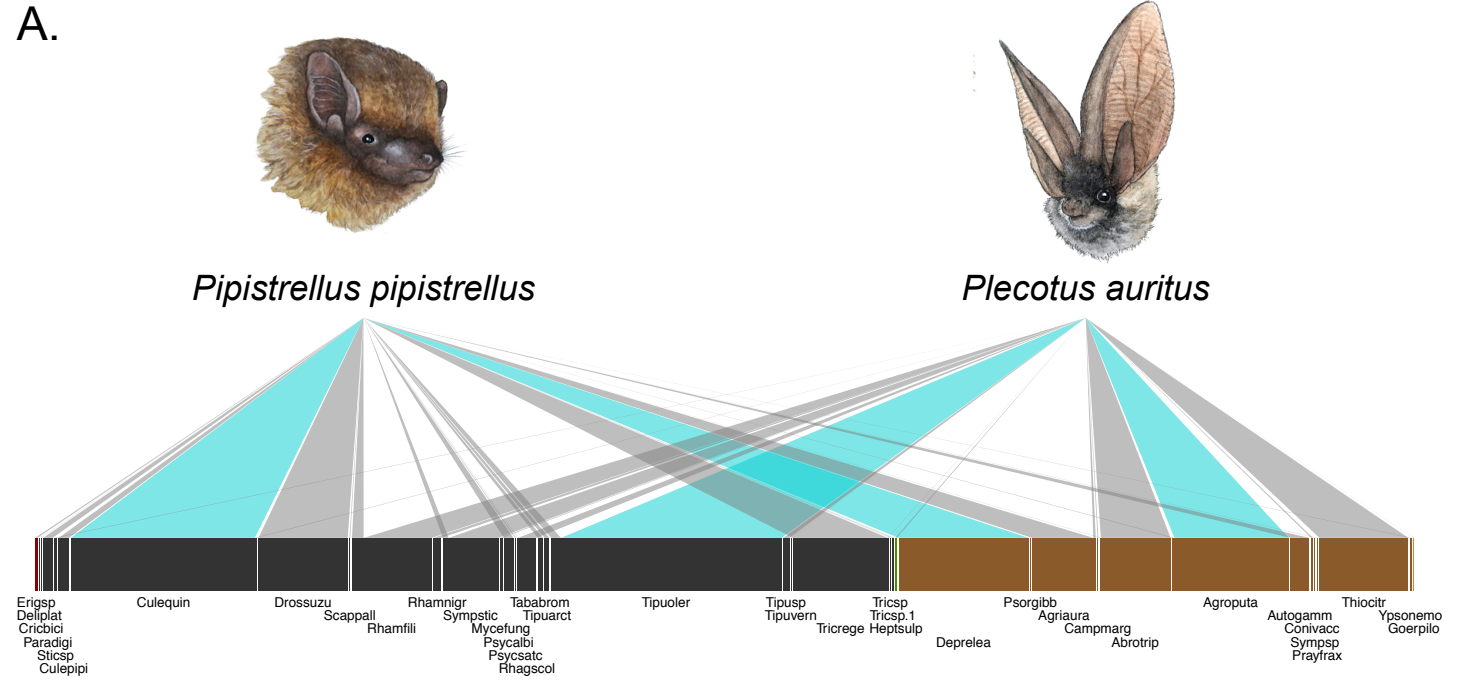

B.
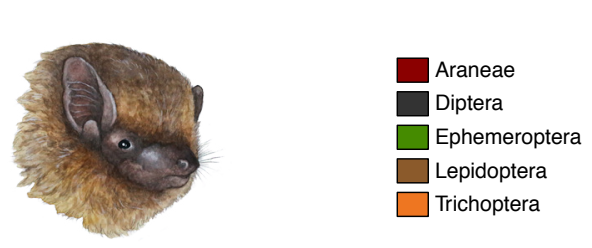

Pipistrellus pipistrellus

Plecotus auritus

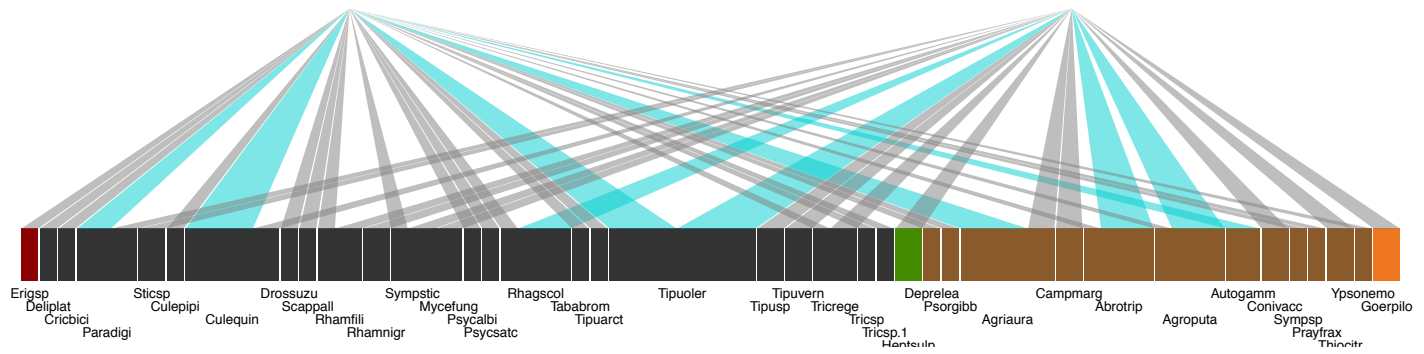

Fig. 1 - Bipartite graphs of the two bat species and their prey species. The upper rows represent predators and the blocks in the lower rows the prey species. A line connecting a predator with a prey represents a detected predation record, and the thickness of the line represents A) the relative read abundance (RRA; see Deagle et al. 2019) or B) the percentage of occurrence (POO; Deagle et al. 2019) in the diet. The abbreviations below the lower blocks correspond to the prey species in Table 2. Bat drawings: Maija Laaksonen.

Table 1 - Overview of the samples, with bat species, type of sample, capture date, latitude \& longitude (WGS84), and fruit type of the orchards.

\begin{tabular}{|c|c|c|c|c|c|c|}
\hline ID & Bat species & Type of sample & Date & Lat & Lon & Fruit types at the study sites \\
\hline 1 & P. pipistrellus & $\begin{array}{l}\text { Sample from a } \\
\text { maternity roost }\end{array}$ & $17 / 08 / 2016$ & 50.773 & 5.159 & $\begin{array}{c}\text { Building: Surrounded by a mix of orchards } \\
\text { of Sweet Cherry, Apple, Pear, Strawberry, } \\
\text { Blackberry, Raspberry }\end{array}$ \\
\hline 2 & P. pipistrellus & $\begin{array}{l}\text { Combined } \\
\text { sample of } 3 \\
\text { adult females }\end{array}$ & 04/08/2016 & 50.899 & 5.222 & Orchard: Mix of Apple \& Pear \\
\hline 3 & P. pipistrellus & $\begin{array}{l}\text { Combined } \\
\text { sample of } 3 \\
\text { adult females }\end{array}$ & 08/08/2016 & 50.730 & 5.243 & Forest nearby orchards of Cherry, Apple \& Pear \\
\hline 4 & P. pipistrellus & $\begin{array}{l}\text { Sex and age } \\
\text { unknown }\end{array}$ & $24 / 08 / 2016$ & 50.898 & 5.402 & Mix of Sweet Cherry, Apple \& Pear \\
\hline 5 & P. pipistrellus & $\begin{array}{l}\text { Combined } \\
\text { sample of } 3 \\
\text { adult females }\end{array}$ & 08/08/2016 & 50.730 & 5.243 & $\begin{array}{l}\text { Forest edge near orchard of Cherry, Apple \& } \\
\text { Pear }\end{array}$ \\
\hline 6 & P. auritus & $\begin{array}{l}\text { Sample from a } \\
\text { maternity roost }\end{array}$ & $17 / 08 / 2016$ & 50.773 & 5.159 & $\begin{array}{c}\text { Building: Surrounded by a mix of orchards of } \\
\text { Sweet Cherry, Apple, Pear, Apricot, Strawberry, } \\
\text { Blackberry, Raspberry }\end{array}$ \\
\hline 7 & P. auritus & Adult female & $21 / 05 / 2016$ & 50.913 & 5.391 & Sweet Cherry \\
\hline 8 & P. auritus & Adult female & $21 / 05 / 2016$ & 50.913 & 5.391 & Sweet Cherry \\
\hline
\end{tabular}


Table 2 - The prey taxa identified in the study, with the relative proportion of reads in each bat species' samples. The abbreviations in the first column correspond to Fig. 1

\begin{tabular}{|c|c|c|c|c|c|}
\hline & Higher taxa & Species & Host and pest status & P. pipistrellus & P. auritus \\
\hline & ARACHNIDA & & & & \\
\hline & Araneae & & & & \\
\hline \multirow[t]{3}{*}{ Erigsp } & Linyphiidae & Erigone sp. & & 0.41 & 0 \\
\hline & INSECTA & & & & \\
\hline & Diptera & & & & \\
\hline Deliplat & Anthomyiidae & Delia platura & $\begin{array}{c}\text { Phaseolus vulgaris, Zea mays; } \\
\text { EPPO } 2020\end{array}$ & 0.04 & 0 \\
\hline Cricbici & \multirow{3}{*}{ Chironomidae } & Cricotopus bicinctus & & 0.08 & 0 \\
\hline Paradigi & & Parachironomus digitalis & & 2.35 & 0.02 \\
\hline Sticsp & & Stictochironomus sp.1 & & 0 & 0.45 \\
\hline Culepipi & \multirow{2}{*}{ Culicidae } & Culex pipiens & & 1.87 & 0 \\
\hline Culequin & & Culex sp. & & 9.7 & 0.35 \\
\hline Drossuzu & \multirow[t]{2}{*}{ Drosophilidae } & Drosophila suzukii & $\begin{array}{l}\text { Fruit crops; Rota-Stabelli et al. } \\
\qquad 2013\end{array}$ & 2.71 & 0 \\
\hline Scappall & & Scaptomyza pallida & & 0.21 & 0 \\
\hline Rhamfili & \multirow{2}{*}{ Empididae } & Rhamphomyia sp.1 & & 2.1 & 0.24 \\
\hline Rhamnigr & & Rhamphomyia sp.2 & & 0 & 0.03 \\
\hline Sympstic & Limoniidae & Symplecta stictica & & 1.02 & 0.18 \\
\hline Mycefung & Mycetophilidae & Mycetophila fungorum & & 0 & 0.56 \\
\hline Psycalbi & \multirow{2}{*}{ Psychodidae } & Psychoda albipennis & & 2.33 & 0 \\
\hline Psycsatc & & Psychoda satchelli & & 0.23 & 0 \\
\hline Rhagscol & Rhagionidae & Rhagio scolopaceus & & 0.08 & 3.49 \\
\hline Tababrom & Tabanidae & Tabanus bromius & & 0.87 & 0 \\
\hline Tipuarct & \multirow{4}{*}{ Tipulidae } & Tipula sp.1 & & 0.86 & 0 \\
\hline Tipuoler & & Tipula oleracea & $\begin{array}{c}\text { Fruit crops; Carter 1984, Hill } \\
\text { 2002, Bailey 2007, Alford 2012, } \\
2014\end{array}$ & 0.18 & 56.39 \\
\hline Tipusp & & Tipula sp.2 & & 0 & 1.18 \\
\hline Tipuvern & & Tipula vernalis & & 0 & 0.03 \\
\hline Tricrege & \multirow{3}{*}{ Trichoceridae } & Trichocera regelationis & & 23.5 & 0.1 \\
\hline Tricsp & & TrichoceridaelntGen1 sp. & & 0.18 & 0 \\
\hline Tricsp.1 & & TrichoceridaelntGen2 sp. & & 0.32 & 0 \\
\hline Heptsulp & Ephemeroptera & & & & \\
\hline \multirow[t]{2}{*}{ Deprelea } & Heptageniidae & Heptagenia sulphurea & & 0 & 0.27 \\
\hline & Lepidoptera & & & & \\
\hline Psorgibb & Depressariidae & Depressaria sp. & & 38.75 & 0 \\
\hline Agriaura & Gelechiidae & Psoricoptera gibbosella & & 0.04 & 0 \\
\hline
\end{tabular}

gamma in the diet of $P$. pipistrellus and T. oleracea and Campaea margaritaria in the diet of $P$. auritus (Table 2). Some of these were rather common in the diet, as can be seen from the web (Fig. 1). Most other identified taxa in the diet of $P$. pipistrellus included typical prey for aerial-hawking bats such as Chironomidae, Culicidae and other small flies, and several families of Lepidoptera and Trichoptera. Most identified prey taxa in the samples of $P$. auritus were Lepidoptera.

\section{DISCUSSION}

We recovered 37 taxa of 22 arthropod families in our samples. Despite the limited sample size, $D$. suzukii was recorded in one out of the five samples from $P$. pipistrellus. These results indicate that $P$. pipistrellus, the most common species in Belgium, potentially acts as a biological pest controller in orchards. In our study the sample size was low, but in light of earlier findings the pattern becomes more interesting. A 
recent study from France found $D$. suzukii in faecal samples of $R$. hipposideros (1/11), P. pipistrellus (1/31) and P. kuhlii (1/3) (Galan et al. 2018). Moreover, other Drosophilidae species were recorded in the diet of $P$. pygmaeus, Myotis daubentonii, M. brandtii, Eptesicus nilssonii and $P$. auritus in Finland and Sweden (Vesterinen et al. 2013, 2018, Rydell et al. 2016), indicating that other bat species could potentially forage on this species. We recorded four additional pest species that, albeit to a lesser extent, cause damage in agricultural systems. T. oleracea was observed in the samples of both species, while $C$. margaritata was found in the diet of $P$. auritus and $A$. gamma and $D$. platura in the diet of $P$. pipistrellus.

High numbers of $D$. suzukii are active at dawn and dusk, but not during the night (Evans et al. 2017). Pipistrelle bats mainly catch their prey in the air, so they likely feed on flying $D$. suzukii individuals at dawn and dusk. P. pipistrellus emerges relatively early from their roosts (15 to 30 minutes after sunset), and forages close to their roosts (average distance $1.5 \mathrm{~km}$; Dietz \& Kiefer 2016). Especially bats roosting in or near orchards may thus predate on D. suzukii. Monitoring during the whole year shows that $D$. suzukii populations in orchards rapidly grow in August and reach their peak in autumn. During mild winters and in the subsequent spring months, the species remains present (Belien et al. 2014). We recorded $D$. suzukii in a sample collected in late August. It would be of great interest to investigate to what extent the species is preyed upon by bats across the entire season. Future studies should investigate to what extent predation by bats can indeed decrease the population numbers of $D$. suzukii or other pest species. In this context, experimentally excluding bats from crops, and subsequently comparing crop damage or pest numbers with those in control plots would be highly interesting (e.g. Maas et al. 2013, Maine \& Boyles 2015).

Nevertheless, the evidence that a common bat species consumes economically important agricultural pests could already provide incentives for bat conservation in agricultural landscapes (Kross et al. 2018). Many bats are threatened, among other factors due to roost destruction, agricultural intensification and pesticide use (Dietz \& Kiefer 2016). Management actions for bats could thus not only increase potential ecosystem services provided to farmers, but also be vital to conserve bat populations in agricultural landscapes (Russo et al. 2018). Such actions should include the creation and preservation of ponds, hedgerows and treelines both locally and at the landscape scale (Heim et al. 2018), protecting existing roost sites (Russo et al. 2018), avoiding artificial light at night (Stone et al. 2015) and moderating pesticide use (Stahlschmidt \& Brühl 2012).

To conclude, we show that a common bat species preys upon an economically important agricultural pest in Belgian orchards. This indicates that bats could act as biological pest suppressors, and can stimulate future studies.

\section{ACKNOWLEDGEMENTS}

We thank the farmers for allowing the fieldwork on their property, Luc Crevecoeur for his input in the study set-up and Maija Laaksonen for the drawings in Figure 1. We thank two anonymous reviewers for helpful comments on earlier drafts of the manuscript.

\section{REFERENCES}

AIZPURUA, O., BUDINSKI, I., GEORGIAKAKIS, P., GOPALAKRISHNAN, S., IBAÑEZ, C., MATA, V., REBELO, H., RUSSO, D., SZODORAY-PARÁDI, F., ZHELYAZKOVA, V., et al. (2018). Agriculture shapes the trophic niche of a bat preying on multiple pest arthropods across Europe: Evidence from DNA metabarcoding. Molecoluar Ecology, 27(3): 815-825. https://doi.org/10.1111/mec.14474

ALFORD, D. V. (2012). Pests of Ornamental Trees, Shrubs and Flowers: A Colour Handbook. Second edition. ed.: Boston: Academic Press. London, United Kingdom, 480 pp. https://doi.org/10.1201/b15136

ALFORD, D. V. (2014). Pests of fruit crops: A Colour Handbook. Second edition. ed.: New York: CRC Press. Boca Raton, Florida, United States of America, 462 pp. https://doi.org/10.1201/b17030

ASPLEN, M. K., ANFORA, G., BIONDI, A., CHOI, D. -S., CHU, D., DAANE, K. M., GILBERT, P., GUTIERREZ, A. P., HOELMER, K. A., HUTCHISON, W. D., et al. (2015). Invasion biology of spotted wing Drosophila (Drosophila suzukii): a global perspective and future priorities. Journal of Pest Science, 88: 469-494. https://doi.org/10.1007/ s10340-015-0681-z

BAILEY, P. T. (2007). Pests of field crops and pastures: Identification and control. ed.: Collingwood: Csiro Publishing. Malaysia, 520 pp.

BELIEN, T., THYS, T., FASSOTTE, C., WALRANT, C., TOMME, M., BOLEN, M. \& BYLEMANS, D. (2014). Population dynamics of Drosophila suzukii (diptera: drosophilidae) in belgium in 2013. Communications in Agricultural and Applied Biological Sciences, 79(2): 169-75.

BOYLES, J. G., CRYAN, P. M., MCCRACKEN, G. F. \& KUNZ, T. H. (2011). Economic importance of bats in agriculture. Science, 332(6025): 41-42. https://doi.org/10.1126/ science. 1201366

CARTER, D. J. (1984). Pest Lepidoptera of Europe: With Special Reference to the British Isles. ed.: Springer Netherlands. Dordrecht, Netherlands, 431 pp.

CLARKE, L. J., SOUBRIER, J., WEYRICH, L. S. \& COOPER, A. (2014). Environmental metabarcodes for insects: in silico PCR reveals potential for taxonomic bias. Molecular Ecology Resources, 14(6): 1160-1170. https://doi. org/10.1111/1755-0998.12265 
DEAGLE, B. E., THOMAS, A. C., McINNES, J. C., CLARKE, L. J., VESTERINEN, E. J., CLARE, E. L., KARTZINEL, T. R. \& EVESON, J. P. (2019). Counting with DNA in metabarcoding studies: How should we convert sequence reads to dietary data? Molecular Ecology, 28(2): 391-406. https://doi.org/10.1111/mec.14734

DIETZ, C. \& KIEFER, A. (2016). Bats of Britain and Europe. ed.: Bloomsbury. London, United Kingdom, 398 pp.

DORMANN, C. F., FRÜND, J., BLÜTHGEN, N. \& GRUBER, B. (2009). Indices, graphs and null models: analyzing bipartite ecological networks. The Open Ecology Journal, 2: 7-24. https://doi.org/10.2174/1874213000902010007

EDGAR, R. C. (2010). Search and clustering orders of magnitude faster than BLAST. Bioinformatics, 26(19): 2460-2461. https://doi.org/10.1093/bioinformatics/ btq461

EDGAR, R. C. (2016). UNOISE2: improved error-correction for Illumina $16 \mathrm{~S}$ and ITS amplicon sequencing. bioRxiv, 081257. https://doi.org/10.1101/081257

EPPO. (2020). EPPO Global Database (online). https:// gd.eppo.int

EVANS, R. K., TOEWS, M. D. \& SIAL, A. A. (2017). Diel periodicity of Drosophila suzukii (Diptera: Drosophilidae) under field conditions. PLOS ONE, 12(2): e0171718. https://doi.org/10.1371/journal.pone.0171718

FAO. (2020). The Food and Agriculture Organization of the United Nations. NSP - Integrated Pest Management.

GALAN, M., PONS, J. B., TOURNAYRE, O., PIERRE, É., LEUCHTMANN, M., PONTIER, D. \& CHARBONNEL, N. (2018). Metabarcoding for the parallel identification of several hundred predators and their prey: Application to bat species diet analysis. Molecular Ecology Resources, 18(3): 474-489. https://doi.org/10.1111/17550998.12749

HEIM, O., LENSKI, J., SCHULZE, J., JUNG, K., KRAMERSCHADT, S., ECCARD, J. A. \& VOIGT, C. C. (2018). The relevance of vegetation structures and small water bodies for bats foraging above farmland. Basic and Applied Ecology, 27: 9-19. https://doi.org/10.1016/j. baae.2017.12.001

HILL, D. S. (2002). Pests of stored foodstuffs and their control. ed.: Kluwer academic publishers. Dordrecht, Netherlads, $475 \mathrm{pp}$.

KAUNISTO, K. M., ROSLIN, T., SÄÄKSJÄRVI, I. E. \& VESTERINEN, E. J. (2017). Pellets of proof: First glimpse of the dietary composition of adult odonates as revealed by metabarcoding of feces. Ecology and Evolution, 7(20): 8588-8598. https://doi.org/10.1002\%2Fece3.3404

KROSS, S. M., INGRAM, K. P., LONG, R. F. \& NILES, M. T. (2018). Farmer Perceptions and Behaviors Related to Wildlife and On-Farm Conservation Actions. Conservation Letters, 11(1): e12364. https://doi.org/10.1111/ conl.12364
KRÜGER, F., CLARE, E. L., SYMONDSON, W. O. C., KEIŠS, O. \& PÉTERSONS, G. (2014). Diet of the insectivorous bat Pipistrellus nathusii during autumn migration and summer residence. Molecular Ecology, 23(15): 36723683. https://doi.org/10.1111/mec.12547

MAAS, B., CLOUGH, Y. \& TSCHARNTKE, T. (2013). Bats and birds increase crop yield in tropical agroforestry landscapes. Ecology Letters, 16(12): 1480-1487. https:// doi.org/10.1111/ele.12194

MAINE, J. J. \& BOYLES, J. G. (2015). Bats initiate vital agroecological interactions in corn. Proceedings of the National Academy of Sciencies of the United States of America, 112(40): 12438-12443. https://doi. org/10.1073/pnas.1505413112

MARTIN, M. (2011). Cutadapt removes adapter sequences from high-throughput sequencing reads. EMBnet. Journal, 17(1): 10-12. https://doi.org/10.14806/ ej.17.1.200

MORTELMANS, J., CASTEELS, H. \& BELIËN, T. (2012). Drosophila suzukii (Diptera: Drosophilidae): A pest species new to Belgium. Belgian Journal of Zoology, 142(2): 143-146.

NIJLAND, R. (2015). Zoeken naar de zwakke plek van suzuki. Wageningen world, 2: 22-27.

R Core Team (2017). R: A language and environment for statistical computing. R Foundation for Statistical Computing, Vienna, Austria. https://www.R-project.org/

RATNASINGHAM, S. \& HEBERT, P. D. N. (2007). Bold: The Barcode of Life Data System (http://www.barcodinglife. org). Molecular Ecology Notes, 7(3): 355-364. https:// doi.org/10.1111/j.1471-8286.2007.01678.x

ROTA-STABELLI, O., BLAXTER, M. \& ANFORA, G. (2013). Drosophila suzukii. Current Biology, 23(1): R8-R9. https:// doi.org/10.1016/j.cub.2012.11.021

RUSSO, D., BOSSO, L. \& ANCILLOTTO, L. (2018). Novel perspectives on bat insectivory highlight the value of this ecosystem service in farmland: Research frontiers and management implications. Agriculture, Ecosystems \& Environment, 266: 31-38. https://doi.org/10.1016/j. agee.2018.07.024

RYDELL, J., BOGDANOWICZ, W., BOONMAN, A., PETTERSSON, S., SUCHECKA, E. \& POMORSKI, J. J. (2016). Bats may eat diurnal flies that rest on wind turbines. Mammalian Biology, 81(3): 331-339. https:// doi.org/10.1016/j.mambio.2016.01.005

SCHETELIG, M. F., LEE, K. -Z., OTTO, S., TALMANN, L., STÖKL, J., DEGENKOLB, T., VILCINSKAS, A. \& HALITSCHKE, R. (2018). Environmentally sustainable pest control options for Drosophila suzukii. Journal of Applied Entomology, 142(1-2): 3-17. https://doi.org/10.1111/jen.12469 
STAHLSCHMIDT, P. \& BRÜHL, C. A. (2012), Bats at risk? Bat activity and insecticide residue analysis of food items in an apple orchard. Environmental Toxicology and Chemestry, 31(7): 1556-1563. https://doi.org/10.1002/ etc.1834

STAHLSCHMIDT, P., HAHN, M. \& BRÜHL, C. A. (2017). Nocturnal Risks-High Bat Activity in the Agricultural Landscape Indicates Potential Pesticide Exposure. Frontiers in Environmental Science, 5: 62. https://doi. org/10.3389/fenvs.2017.00062

STONE, E. L., HARRIS, S. \& JONES, G. (2015). Impacts of artificial lighting on bats: A review of challenges and solutions. Mammalian Biology, 80(3): 213-219. https:// doi.org/10.1016/j.mambio.2015.02.004

VESTERINEN, E. J., LILLEY, T., LAINE, V. N. \& WAHLBERG, N. (2013). Next Generation Sequencing of Fecal DNA Reveals the Dietary Diversity of the Widespread Insectivorous Predator Daubenton's Bat (Myotis daubentonii) in Southwestern Finland. PLoS ONE, 8(11): e82168. https:// doi.org/10.1371/journal.pone.0082168
VESTERINEN, E. J., RUOKOLAINEN, L., WAHLBERG, N., PEÑA, C., ROSLIN, T., LAINE, V. N., VASKO, V., SÄÄKSJÄRVI, I. E., NORRDAHL, K. \& LILLEY, T. M. (2016), What you need is what you eat? Prey selection by the bat Myotis daubentonii. Molecular Ecology, 25(7): 1581-1594. https://doi.org/10.1111/mec.13564

VESTERINEN, E. J., PUISTO, A. I. E., BLOMBERG, A. S. \& LILLEY, T. M. (2018). Table for five, please: Dietary partitioning in boreal bats. Ecology and Evolution, 8(22): 10914-10937. https://doi.org/10.1002/ece3.4559

ZEALE, M. R. K., BUTLIN, R. K., BARKER, G. L. A., LEES, D. C. \& JONES, G. (2011). Taxon-specific PCR for DNA barcoding arthropod prey in bat faeces. Molecular Ecology Resources, 11(2): 236-244. https://doi.org/10.1111/ j.1755-0998.2010.02920.x 